\title{
Analisis Tingkat Efisiensi BPRS di Jawa Barat dengan Metode Data Envelopment Analysis (DEA)
}

\section{Efficiency analysis of BPRS in West Java with the data envelopment analysis method (DEA)}

\section{Iqlima Yulian Pebrianti}

Program Studi D4 Keuangan Syariah, Politeknik Negeri Bandung

E-mail: iqlimayulian@gmail.com

\begin{abstract}
Global Islamic banking has developed rapidly. However, various challenges are still faced by Islamic banking, one of them is efficiency. This study aims to reveal the level efficiency of BPRS and to show the most inefficient variables. This research is quantitative descriptive. The sample is BPRS in West Java. The input variables used in this study: total savings, labor costs, total fixed assets, and capital. The Output is: total financing and other operating income with DEA,VRS model and intermediation approach for the method. The results of this study indicate that BPRS in West Java are still experiencing a fluctuating trend of efficiency and have an average efficiency of 94.52\%. This shows that the BPRS in West Java are not yet efficient, but the BPRS in West Java are approaching the point of efficiency and are good enough in carrying out their role as intermediary institutions.
\end{abstract}

Keywords: efficiency, DE $A, V R S$, intermediation approach.

\section{Pendahuluan}

Dalam dua dekade terakhir, industri keuangan Islam telah muncul dalam ekonomi dunia. Asset perbankan syariah global telah berkembang pesat (Zarrouk et al., 2017). Perkembangan tersebut ditandai dengan peningkatan asset keuangan Islam dunia yang terus berkembang dan mencapai US\$2,52 triliun pada tahun 2018 (Reuters \& Standard, 2018). Perbankan syariah berkontribusi 70 persen dari total asset keuangan Islam dengan jumlah total asset mencapai US\$ 1,76 triliun dan memiliki 520 bank syariah di 72 negara (IFDI, 2019). Dalam kondisi perekonomian yang sedang berkembang sektor perbankan memiliki peluang besar dalam peranannya sebagai lembaga intermediasi keuangan (Setiawan \& dkk, 2020).

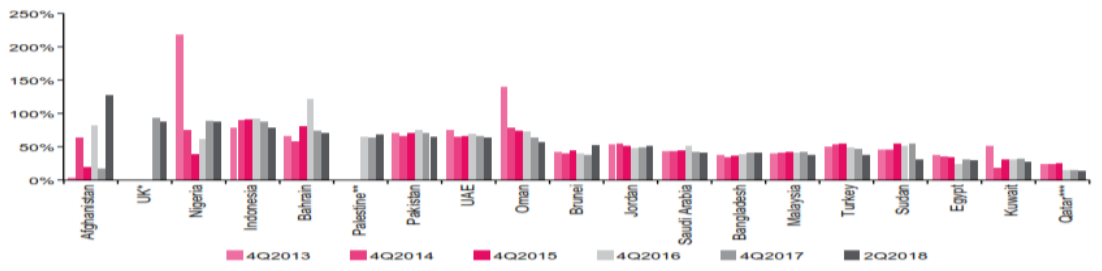

Gambar 1. Cost to Income Ratio (CIR) Negara-Negara Perbankan Syariah Dunia Sumber: Islamic Financial Services Industry Stability Report 2019

Sekalipun mengalami perkembangan yang cukup pesat, berbagai tantangan masih dihadapi oleh perbankan syariah. Salah satunya adalah efisiensi perbankan syariah yang cenderung lebih rendah dari nilai yang ideal (Hardianto \& Wulandari, 2016). Begitu pula dalam menghadapi 
persaingan yang ketat di dunia perbankan, efisiensi bank syariah masih rendah dari bank konvensional (Mokhtar, 2006). Permasalahan tersebut dapat dilihat dari cost to income ratio (CIR) beberapa negara perbankan syariah dunia.

Pada tahun 2013-2018 beberapa negara masih memiliki rasio CIR di atas 50\% diantaranya adalah Afganistan, United Kingdom, Nigeria, Indonesia, Bahrain, Palestine, Pakistan, Uni Emirat Arab, Oman, Turkey, dan Sudan (IFSB, 2019). Rasio tersebut mencerminkan sebagian besar perbankan syariah dunia belum efisien. Inefisiensi yang terjadi menunjukan bahwa fungsi bank sebagai lembaga intermediasi tidak berjalan optimal yang akan berdampak pada profitabilitas perbankan syariah itu sendiri (Hardianto \& Wulandari, 2016) dan ketidakmampuan bersaing dapat membuang perbankan syariah keluar dari pasar, baik itu dalam persaingan harga, kualitas produk dan pelayanan (Hidayah, 2014). Sedangkan negara yang memiliki rasio efisiensi dibawah 50\% diantaranya adalah Brunei, Saudi Arabia, Bangladesh, Jordan, Malaysia, Egypt, Kuwait, dan Qatar. Rasio ini menunjukan nilai efisiensi yang lebih baik walaupun belum mencapai nilai yang optimal. Oleh sebab itu, investigasi terhadap tingkat efisiensi perbankan syariah dan bagaimana cara meningkatkan kinerja efisiensi tersebut perlu dilakukan.

Memahami pentingnya penelitian tentang efisiensi pada perbankan syariah, para peneliti terdahulu telah melakukan analisis terhadap masalah efisiensi di industri tersebut. Objek-objek yang diteliti pada umumnya adalah Bank Umum Syariah dan Lembaga Mikro Syariah, para peneliti yang melakukan pengujian tersebut adalah (Fadzlan Sufian 2015; Ascarya 2017; Dimas Satria H. 2016). Sayangnya, analisis terhadap Bank Pembiayaan Rakyat Syariah (BPRS) masih sedikit yang melakukan, diantaranya adalah (Suci Marawati 2016; Aris Kristianto 2018; Emir Hamara 2017). Variabel input yang digunakan oleh para penulis tersebut dalam menganalisis tingkat efisiensi adalah total DPK, biaya tenaga kerja, dan total asset, sedangkan variabel output yang digunakan adalah pembiayaan dan pendapatan operasional. Menurut Ascarya (2017) dalam penelitiannya mengenai efisiensi koperasi konvensional dan BMT dengan metode DEA pendekatan intermediasi, ia menggunakan variabel modal pada input dan mengungkapkan bahwa masalah umum koperasi dan BMT adalah pendanaan dan ekuitas sebagai sumber dana utama mereka untuk memperluas pembiayaan mikro. Namun sampai saat ini belum ada penelitian mengenai efisiensi BPRS dengan menambahkan variabel modal pada input. Oleh sebab itu, agar lebih komprehensif maka penelitian efisiensi BPRS yang memanfaatkan variabel imput; total simpanan, biaya tenaga kerja, total asset tetap, modal, variabel output total pembiayaan dan pendapatan operasional lainnya perlu dilakukan. Masuknya variabel ini sebagai penyempurna analisis efisiensi pada BPRS didasarkan rekomendasi Emir Hamara (2017) dalam penelitiannya untuk menambah variabel, menambah jumlah sampel dan tahun penelitian pada penelitian efisiensi selanjutnya.

Penulis memilih Bank Pembiayaan Rakyat Syariah (BPRS) Indonesia sebagai objek penelitian karena menurut data Otoritas Jasa Keuangan (2019) kinerja BPRS Indonesia belum optimal hal ini ditunjukan dengan beberapa alasan berikut; (1) Tidak terjadi perubahan yang signifkan pada BOPO BPRS di Indonesia selama 5 tahun terakhir. Rasio tersebut terbilang tinggi yaitu 87,79\% pada tahun 2014 dan 87,66\% pada tahun 2018, meskipun masih berada di bawah ketentuan maksimum Bank Indonesia. Hal ini mencerminkan kinerja BPRS yang masih belum efisien dalam mengelola dananya artinya biaya yang dikeluarkan lebih besar dari profit yang didapat. (2) NPF BPRS yang terus meningkat selama 5 tahun terakhir. NPF meningkat dari 7,89\% pada tahun 2014 dan $9.30 \%$ pada tahun 2018. NFP merupakan perbandingan antara jumlah pembiyaan non lancar dengan kualitas kurang lancar, diragukan atau macet (Hijriyani \& Setiawan, 2017). Semakin tinggi NPF suatu bank menunjukan bahwa kinerja bank tersebut semakin buruk (Basse \& Mulazid, 2017), begitu pula yang terjadi pada BPRS di Indonesia saat ini.

Penulis memilih Jawa Barat sebagai polulasi penelitian karena Jawa Barat provinsi dengan penduduk terbanyak di Indonesia, Perekonomian Jawa Barat berkembang baik setiap tahunnya. 
Hal ini ditandai dengan berkembangnya sektor UMKM di Jawa Barat. Menurut data Badan Pusat Statistik jumlah UMKM di Jawa Barat berkembang berfluktuatif dari tahun ke tahun. Pada tahun 2014 jumlah UMKM di Jawa Barat mencapai 498.003 dan terus berkembang hingga pada tahun 2018 mencapai 536.207. Hal ini menggambarkan kebutuhan akan pembiayaan di Jawa Barat yang cukup tinggi dan tentu berpengaruh pada potensi BPRS sebagai lembaga intermediasi dalam menyalurkan dana dalam bentuk pembiayaan kepada UMKM. Menurut data Otoritas Jasa Keuangan (2018) total asset BPRS Jawa Barat mengalami peningkatan dari Rp 1.930.188 pada tahun 2014 menjadi Rp 3.837.186 pada tahun 2018. Jaringan kantor BPRS di Jawa Barat merupakan yang paling banyak di Indonesia. Namun bila dilihat dari jumlah jaringan kantor BPRS di Jawa Barat selama 5 tahun terakhir tidak terjadi perkembangan, yaitu sebanyak 28 kantor.

Tabel 1. Perkembangan BPRS di Jawa Barat Periode 2014-2018

\begin{tabular}{|l|c|c|c|c|c|}
\hline \multicolumn{1}{|c|}{ Indikator } & $\mathbf{2 0 1 4}$ & $\mathbf{2 0 1 5}$ & $\mathbf{2 0 1 6}$ & $\mathbf{2 0 1 7}$ & $\mathbf{2 0 1 8}$ \\
\hline Jumlah kantor & 28 & 28 & 28 & 28 & 28 \\
\hline Aset (Juta Rp) & 1.930 .188 & 2.300 .411 & 2.824 .146 & 3.336 .569 & 3.837 .186 \\
\hline $\begin{array}{l}\text { Pembiayaan sektor } \\
\text { UMKM (Juta Rp) }\end{array}$ & 955.423 & 1.147 .826 & 1.033 .678 & 1.081 .761 & 1.166 .976 \\
\hline NPF (\%) & 7,95 & 6,71 & 5,35 & 7,56 & 7,57 \\
\hline
\end{tabular}

Sumber : Statistik Perbankan Syariah OJK Periode 2014-2018

Seperti yang terlihat pada tabel I.1 bahwa perkembangan BPRS di Jawa Barat dapat terlihat dari pembiayaan untuk sektor UMKM BPRS yang meningkat dari Rp 955.423 pada tahun 2014 menjadi Rp 1.166.976 pada tahun 2018. Namun dapat kita lihat BPRS di Jawa Barat masih memiliki NPF yang tinggi, yaitu sebesar 7,56 persen pada tahun 2018. Hal tersebut mencerminkan bahwa BPRS di Jawa Barat belum efisien dalam mengelola dananya.

Berdasarkan uraian tersebut penulis menemukan adanya permasalahan efisiensi pada kinerja BPRS. Oleh sebab itu, perlu dilakukan studi yang dapat mengungkap tingkat efisiensi BPRS secara umum dan menunjukan variabel yang paling tidak efisien. Dari temuan tersebutlah maka solusi atas permasalahan efisiensi pada BPRS dapat ditemukan. Dengan itu penulis tertarik untuk melakukan penelitian dengan judul: Analisis Tingkat Efisiensi Bank Pembiayaan Rakyat Syariah di Jawa Barat dengan Metode Data Envelopment Analysis (DEA).

\section{Kajian Pustaka}

\section{Pengertian Efisiensi}

Menurut Hidayat (2011) efisiensi adalah rasio antara output dan imput. Suatu perusahaan termasuk perbankan dapat dikatakan efisien jika mampu menghasilkan output lebih banyak dibandingkan input yang dikeluarkan. Atau menghasilkan output yang sama tetapi input yang dikeluarkan lebih sedikit. Efisiensi juga bisa disebut sebagai gambaran kemampuan dalam menghasilkan output yang maksimal dengan input yang ada atau merupakan ukuran kinerja yang diharapkan (Setyowati, 2018). 


\section{Efisiensi Perbankan}

Perbankan sebagai lembaga intermediasi keuangan memiliki peran penting dalam perekonomian suatu negara. Oleh karena itu, bank dituntut untuk memiliki kinerja yang sehat atau baik. Indikator kinerja yang baik tersebut salah satunya dapat dilihat dari tingkat efisiensi yang dicapai oleh bank. Menurut Muharam \& Pusvitasari (2007) secara keseluruhan efisiensi perbankan dapat berupa; pertama, efisiensi skala (scale efficiency) yaitu bank mengalami efisiensi dalam skala ketika bank mampu beroperasi dalam skala hasil yang konstan. Kedua, efisiensi dalam cakupan (scope efficiency) yaitu efisiensi cakupan bisa tercapai ketika bank dapat beroperasi pada diversifikasi lokasi. Ketiga, efisiensi alokasi (allocative efficiency) yaitu bank dapat mencapai efisiensi ketika bank bisa menentukan berbagai output yang dapat memaksimalkan keuntungan. Keempat, efisiensi teknis (technical efficiency) yaitu efisiensi ini biasanya menyatakan hubungan antara input dan output dalam suatu proses produksi.

\section{Pengukuran Efisiensi}

Menurut Muharam \& Pusvitasari (2007) Pengukuran efisiensi dapat dilakukan melalui tiga pendekatan. Pertama, pendekatan rasio yaitu pendekatan dalam mengukur efisiensi dilakukan dengan cara menghitung perbandingan output dan input yang digunakan. Pendekatan rasio akan dinilai memiliki efisiensi yang tinggi apabila dapat memproduksi jumlah output yang maksimal dengan jumlah input yang seminimal mungkin. Kedua, pendekatan regresi yaitu pendekatan yang mengukur efisiensi menggunakan sebuah model dari tingkat output tertentu sebagai fungsi dari berbagai tingkat input tertentu. Fungsinya dapat disajikan sebagai $\mathrm{Y}=\mathrm{f}\left(\mathrm{X}_{1}, \mathrm{X}_{2}, \mathrm{X}_{3}, \ldots \mathrm{X}_{\mathrm{n}}\right)$ di mana, $\mathrm{Y}$ adalah Output dan X adalah Input. Pendekatan regresi akan menghasilkan estimasi hubungan yang dapat digunakan untuk memproduksi tingkat output yang dihasilkan sebuah Unit Kerja Ekonomi (UKE) pada tingkat input tertentu. UKE tersebut akan dinilai efisien bila mampu mengahasilkan jumlah output lebih banyak dibandingkan jumlah output hasil estimasi. Ketiga, pendekatan frontier yaitu pendekatan yang membedakan pengukuran efisiensi menjadi dua jenis, yaitu pendekatan parametik dan non-parametik. Pendekatan frontier parametik diukur dengan tes statistik parametik seperti Stochastic Frontier Approach (SFA) dan Distribution Free Approach (DFA). Pendekatan frontier non-parametik diukur dengan tes statistik non-parametik yaitu dengan menggunkan metode Data Envelopment Analysis (DEA).

\section{Penentuan Variabel Input dan Output}

Pada penelitian ini penulis menggunakan pendekatan intermediasi, karena menurut Berger \& Humphrey (1997) menggungkapkan bahwa pendekatan yang paling tepat untuk mengevaluasi kinerja lembaga keuangan secara umum adalah pendekatan intermediasi, karena fungsi lembaga keuangan yang menghimpun dana dari surplus unit dan menyalurkannya kepada defisit unit. Berikut adalah variabel yang digunakan dalam penelitian.

Tabel 2. Variabel Input dan Output

\begin{tabular}{|c|c|c|}
\hline Variabel & Sumber & Literatur \\
\hline Total simpanan (I1) & Neraca & Fadzlan Sufian (2015) \\
\hline Biaya tenaga kerja (I2) & Laba/rugi & Fadzlan Sufian (2015) \\
\hline Total asset tetap (I3) & Neraca & Fadzlan Sufian (2015) \\
\hline Modal (I4) & Neraca & Ascarya (2017) \\
\hline Total pembiayaan (O1) & Neraca & Fadzlan Sufian (2015) \\
\hline Pendapatan operasional lainnya (O2) & Laba/rugi & Ascarya (2017) \\
\hline
\end{tabular}

Sumber: diolah oleh penulis 
Berdasarkan penelitian terdahulu di atas yang telah meneliti mengenai efisiensi pada perbankan dan lembaga mikro syariah, terdapat persamaan variabel-variabel yang digunakan pada penelitian Sufian \& Kamarudin (2015), Mahinda et al. (2015) dan Ascarya (2017). Variabel input diantaranya yaitu total simpanan atau total DPK, biaya tenaga kerja, dan total asset. Sedangkan variabel output pembiayaan dan pendapatan operasional. Sehingga pada penelitian ini penulis mengunakan variabel tersebut. Perbedaan pada penelitian ini adalah penulis menambahkan variabel modal pada input, karena belum ada penelitian mengenai efisiensi BPRS di Jawa Barat yang menambahkan variabel modal pada input. Sebelumnya Ascarya (2017) menggunakan variabel modal sebagai input pada penelitiannya mengenai efisiensi BMT. Sehingga variabel yang digunakan pada penelitian ini yaitu total simpanan, biaya tenaga kerja, total asset, dan modal pada input, serta total pembiayaan dan pendapatan operasional lainnya pada output.

\section{Data Envelopment Analysis (DEA)}

Data Envelopment Analysis (DEA) adalah salah satu metode yang popular untuk mengukur kriteria efisiensi. Penulis memilih metode Data Envelopment Analysis (DEA) sebagai alat analisis, karena menurut Hadad et al. (2003) metode DEA dapat memperoleh hasil yang lebih akurat jika dibandingkan dengan menggunakan analisis rasio keuangan. Konsep DEA pertama kali diperkenalkan oleh Charnes, Cooper dan Rhodes pada tahun 1978 dan 1979. Data Envelopment Analysis (DEA) adalah sebuah pendekatan non parametik yang sering digunakan dalam mengukur efisiensi. Menurut Hamara (2017) menyatakan bahwa pendekatan non-parametik adalah pendekatan yang tidak menetapkan syarat-syarat tertentu, seperti parameter populasi yang menjadi induk sampel penelitiannya, penggunaannya lebih sederhana, dan tidak membutuhkan banyak spesifikasi bentuk fungsi.

\section{Metode Penelitian}

\section{Jenis dan Pendekatan Penelitian}

Jenis penelitian ini adalah penelitian deksriptif kuantitatif, penulis memilih pendekatan tersebut karena penelitian ini menekankan analisis pada data-data numerikal (angka) yang diolah dengan metode statistika, mulai dari pengumpulan data, penafsiran terhadap data tersebut, serta penampilan hasilnya. Tujuan dari penelitian deskriptif ini adalah memberikan gambaran secara sistematis, faktual, dan akurat mengenai fenomena yang diamati. Penelitian ini akan memberikan gambaran tingkat efisiensi Bank Pembiayaan Rakyat Syariah (BPRS) di Jawa Barat Periode 2014 sampai dengan 2018.

\section{Jenis, Sumber, dan Metode Pengumpulan Data}

Penelitian ini menggunakan data sekunder dengan jenis data panel berupa laporan keuangan triwulan Bank Pembiayaan Rakyat Syariah (BPRS) yang terdiri atas neraca dan laporan laba rugi. Metode pengumpulan data dalam penelitian ini adalah penelitian pustaka, di mana penulis dalam memperoleh data-data pendukung menurujuk pada berbagai sumber literatur seperti buku dan jurnal ilmiah serta laporan keuangan BPRS yang dipublikasikan di website resmi Otoritas Jasa Keuangan periode 2014-2018.

\section{Populasi dan Sampel Penelitian}

Populasi dalam penelitian ini adalah Bank Pembiayaan Rakyat Syariah (BPRS) di Jawa Barat yang terdaftar di Otoritas Jasa Keuangan dan telah mempublikasikan laporan keuangan dari tahun 2014 sampai dengan 2018. Populasi tersebut berjumlah 28 Bank Pembiayaan Rakyat Syariah (BPRS). Teknik sampling yang digunakan oleh penulis adalah teknik purposive sampling yaitu teknik penentuan sampel dengan pertimbangan tertentu sesuai dengan kebutuhan penelitian (Sugiono, 2016). Penulis memilih teknik tersebut agar sampel yang dipilih sesuai dengan kriteria yang telah dipilih secara khusus berdasarkan tujuan penelitian ini dan karena tidak semua BPRS menyajikan 
data yang lengkap. Kriteria yang digunakan dalam pengambilan sampel ini adalah sebagai berikut;(1) Bank Pembiayaan Rakyat Syariah (BPRS) yang beroperasi di Jawa Barat dan sudah terdaftar di Otoritas Jasa Keuangan berdasarkan Statistik Perbankan Syariah yang dipublikasikan Otoritas Jasa Keuangan. (2) Memiliki total asset terbesar di wilayah masing-masing Kabupaten/Kota Jawa Barat. (3) Mempublikasikan laporan keuanganya selama periode 2014-2018. (4) Menyajikan data lengkap yang dibutuhkan dalam penelitian ini.Dari kriteria tersebut didapatkan 11 BPRS dengan asset terbesar dari masing-masing Kabupaten dan Kota di Jawa Barat.

Tabel 3. Daftar Sampel Penelitian

\begin{tabular}{|c|l|l|}
\hline No. & \multicolumn{1}{|c|}{ Nama BPRS } & \multicolumn{1}{|c|}{ Kabupaten/Kota } \\
\hline 1. & PT BPRS Harta Insan Karimah Parahyangan & Kabupaten Bandung \\
\hline 2. & PT BPRS Amanah Ummah & Kabupaten Bogor \\
\hline 3. & PT BPRS Mentari & Kabupaten Garut \\
\hline 4. & PT BPRS Artha Fisabilillah & Kabupaten Cianjur \\
\hline 5. & PT BPRS Gotong Royong & Kabupaten Subang \\
\hline 6. & PT BPRS Harta Insan Karimah Cibitung & Kabupaten Bekasi \\
\hline 7. & PT BPRS Harta Insan Karimah Bekasi & Kota Bekasi \\
\hline 8. & PT BPRS Al Salaam Amal Salman & Kota Depok \\
\hline 9. & PT BPRS Baiturridha Pusaka & Kota Bandung \\
\hline 10 & PT BPRS Daarut Tauhiid & Kota Cimahi \\
\hline 11 & PT BPRS Al Wadiah & Kota Tasik \\
\hline
\end{tabular}

Sumber: diolah oleh penulis

\section{Metode Analisis}

Berdasarkan sumber data berupa laporan keuangan triwulan masing-masing BPRS yang diteliti, peneliti memisahkan variabel input dan output dalam program. Pengolahan data dilakukan dengan menggunakan software Win4DEAP. Software akan menghitung distribusi nilai atau skor efisiensi pada masing-masing tahun penelitian. Suatu BPRS dikatakan efisien jika memiliki skor sama dengan 100\% atau 1. Sebaliknya, jika skor semakin mendekati nol maka semakin tidak efisien.

Hasil pengolah data pada program DEA juga dapat melihat sumber ketidakefisienan dengan ukuran peningkatan potensial dari masing-masing input dan output yang tercermin dari potential improvement atau radial improvement. Sedangkan nilai slack movement yang dihasilkan DEA dapat digunakan untuk menentukan target perbaikan efisiensi.

Setelah pengolahan data dilakukan, hasil pengolahan data berupa tingkat efisiensi, potential improvement, slack movement, dan rata-rata efisiensi pertahun akan disajikan dalam tabel. Selanjutnya skor efisiensi akan diklasifikasikan berdasarkan kriteria efisiensi.

Menurut Hidayat (2014) Untuk dapat menentukan tingkat efisiensi dibuat ukuran atau kriteria efisiensi sebagai berikut: 
Tabel 4. Kriteria dan Skor Efisiensi

\begin{tabular}{|c|c|}
\hline Kriteria Efisiensi & Nilai/Score $(\%)$ \\
\hline Tinggi & $81-100$ \\
\hline Sedang & $60-80$ \\
\hline Rendah & $40-59$ \\
\hline Tidak efisien & $<40$ \\
\hline
\end{tabular}

Sumber: Efisiensi Perbankan Syariab: Teori dan Praktek (2014)

Lalu akan dilakukan analisis terhadap tingkat efisiensi, potential improvement, slack movement, dan rata-rata efisiensi pertahun hingga menghasilkan kesimpulan serta saran dari penelitian yang telah dilakukan.

\section{Hasil dan Pembahasan}

Berdasarkan hasil olah data dengan menggunakan metode Data Envelopment Analysis (DEA) menggunakan asumsi Variabel Return to Scale (VRS) dengan software Win4DEAP2 2.1, tingkat efisiensi BPRS di Jawa Barat tahun 2014-2018 dapat dilihat dari tabel IV.1 dibawah.

Tabel 5 Tingkat Efisiensi Bank Pembiayaan Syariah di Jawa Barat (Persen)

\begin{tabular}{|c|l|c|c|c|c|c|}
\hline \multirow{2}{*}{ No } & \multicolumn{2}{|c|}{ Nama BPRS } & \multicolumn{5}{c|}{ Tahun } \\
\cline { 3 - 7 } & & $\mathbf{2 0 1 4}$ & $\mathbf{2 0 1 5}$ & $\mathbf{2 0 1 6}$ & $\mathbf{2 0 1 7}$ & $\mathbf{2 0 1 8}$ \\
\hline 1. & BPRS Harta Insan Karimah Parahyangan & 100,00 & 100,00 & 100,00 & 100,00 & 100,00 \\
\hline 2. & BPRS Amanah Ummah & 100,00 & 100,00 & 98,00 & 100,00 & 100,00 \\
\hline 3. & BPRS Mentari & 79,10 & 84,30 & 100,00 & 96,50 & 94,50 \\
\hline 4. & BPRS Artha Fisabilillah & 100,00 & 100,00 & 100,00 & 62,00 & 100,00 \\
\hline 5. & BPRS Gotong Royong & 100,00 & 72,80 & 100,00 & 100,00 & 100,00 \\
\hline 6. & BPRS Harta Insan Karimah Cibitung & 100,00 & 100,00 & 100,00 & 100,00 & 100,00 \\
\hline 7. & BPRS Harta Insan Karimah Bekasi & 97,00 & 100,00 & 100,00 & 92,10 & 100,00 \\
\hline 8. & BPRS Al Salaam Amal Salman & 90,60 & 91,70 & 73,90 & 85,00 & 85,10 \\
\hline 9. & BPRS Baiturridha Pusaka & 100,00 & 76,50 & 77,80 & 100,00 & 77,60 \\
\hline 10. & BPRS Darut Tauhid & 100,00 & 100,00 & 100,00 & 100,00 & 100,00 \\
\hline 11. & BPRS Al Wadi'ah & 100,00 & 83,60 & 100,00 & 95,40 & 86,10 \\
\hline & \multicolumn{1}{|c|}{ Pencapaian Rata-rata } & 97,00 & 91,70 & 95,40 & 93,70 & 94,80 \\
\hline
\end{tabular}

Sumber: Perhitungan Win4DEAP2 2.1, data diolah

Data pada tabel IV.1 di atas menunjukan bahwa selama periode 2014-2018 efisiensi BPRS di Jawa Barat berfluktuatif dan terdapat 10 BPRS yang telah beroperasi secara efisien dengan asumsi Variabel Return to Scale (VRS), selama periode penelitian setidaknya ada 3 BPRS yang mampu menjaga kestabilan nilai efisiensi 100 persen, yaitu BPRS Harta Insan Karimah Parahyangan, BPRS Harta Insan Karimah Cibitung, BPRS Darut Tauhid, hal ini menunjukan BPRS tersebut mampu 
mengoptimalkan sumber daya atau input dan output yang dimiliki sedangkan 8 BPRS lainnya belum mampu beroperasi secara efisien atau belum mampu mengaja kestabilan efisiensi pada tahun 20142018.

Dari hasil perhitungan efisiensi, inefisiensi yang terjadi pada BPRS di Jawa Barat disebabkan oleh variabel total pembiayaan dan pendapatan operasional lainnya pada output. Namun, secara ratarata inefisiensi yang terjadi lebih besar disebabkan oleh total pembiayaan, artinya dana yang disalurkan untuk pembiayaan pada BPRS belum optimal.

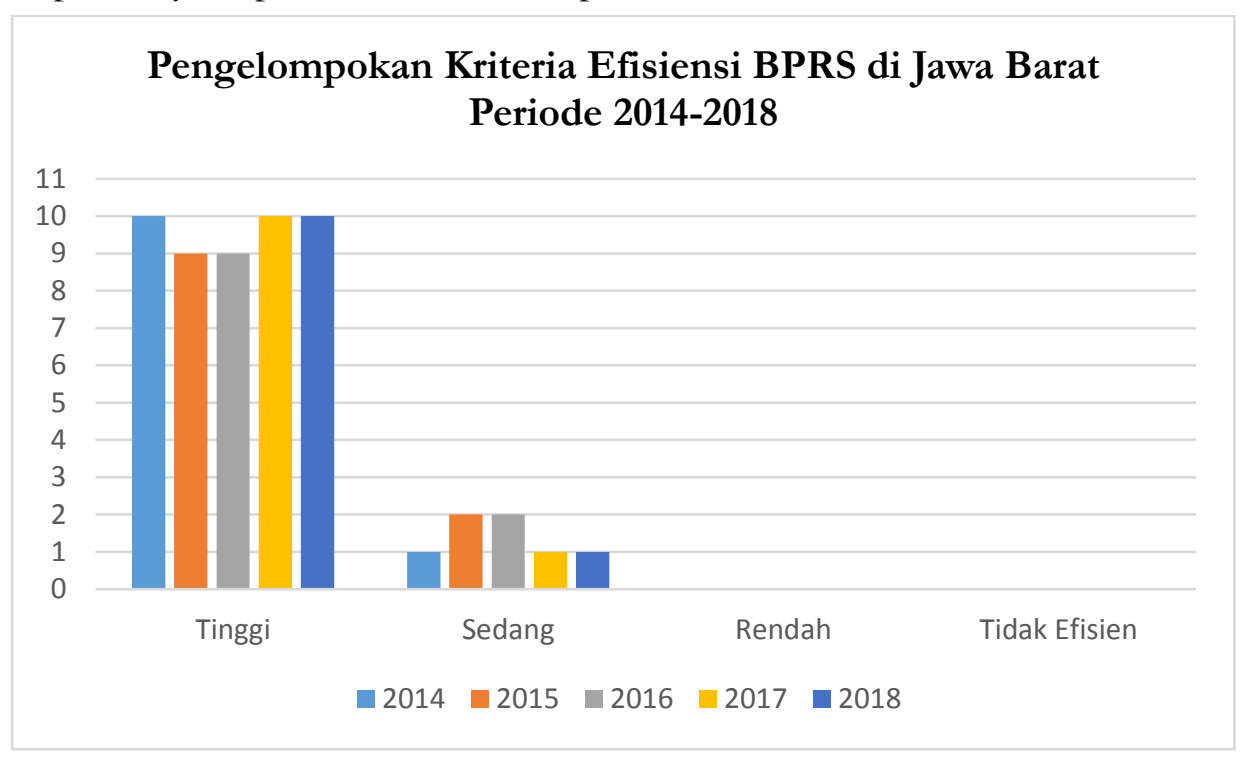

Gambar 2. Pengelompokan Kriteria Efisiensi BPRS di Jawa Barat Periode 2014-2018

Sumber: olah data penulis

Berdasarkan kriteria dan skor efisiensi menurut Hidayat (2014), BPRS di Jawa Barat selama periode 2014-2018 dapat dikategorikan kedalam dua kriteria yaitu tinggi dan sedang. Hal ini menunjukan BPRS sudah cukup baik dalam melaksanakan perannya sebagai lembaga intermediasi.

\section{Implikasi Akademis dan Manajerial}

Secara akademis, penelitian ini berperan dalam memperkaya kajian mengenai efisiensi Bank Pembiayaan Rakyat Syariah (BPRS). Hasil penelitian ini menunjukan nilai rata-rata efisiensi BPRS di Jawa Barat belum efisien. Hal ini sesuai dengan penelitian Hardianto \& Wulandari (2016) yang menyatakan bahwa efisiensi perbankan syariah yang cenderung lebih rendah dari nilai yang ideal. Penelitian ini juga menunjukan bahwa analisis efisiensi perbankan penting untuk dilakukan secara berkelanjutan karena efisiensi merupakan salah satu indikator penilaian kesehatan perbankan. Hal ini perlu dilakukan agar perbankan syariah khususnya BPRS mampu lebih baik dan optimum dalam menjalakan perannya sebagai lembaga intermediasi.

Hasil penelitian ini diharapakan dapat menjadi bahan evaluasi bagi Bank Pembiayaan Rakyat Syariah (BPRS) di Jawa Barat untuk dapat terus meningkatkan dan mempertahankan tingkat efisiensinya. Penelitian ini juga dapat dijadikan pedoman atau bahan pertimbangan bagi berbagai pihak-pihak yang berkepentingan dalam membuat kebijakan ataupun mengambil keputusan dimasa yang akan datang sehingga BPRS di Jawa Barat dapat lebih baik dan efisien dalam menjalankan perannya sebagai lembaga intermediasi, juga mampu bertahan dan bersaing di dunia perbankan. Untuk dapat mencapai nilai efisiensi, BPRS perlu memaksimal sumber daya yang ada dalam kegiatan operasionalnya agar dapat mencapai titik optimal. Dari hasil perhitungan efisiensi dengan Data Envelopment Analysis (DEA) menunjukan banyak BPRS yang belum efisien dalam mengelola jumlah simpanannya. Oleh karena itu, BPRS perlu meningkatkan jumlah penyaluran dana kepada 
produk-produk pembiayaan yang dimana ini merupakan peran utama BPRS itu sendiri. Adapun cara lainnya yaitu dengan menaikan biaya administrasi pada produk Dana Pihak Ketiga sehingga pendapatan operasional BPRS juga dapat sekaligus bertambah. Hal ini tentu harus diiringi dengan peningkatan kualitas jasa pelayanan yang diberikan oleh BPRS kepada nasabah. Inefisiensi juga disebabkan oleh pengeluaran biaya tenaga kerja yang berlebihan. Oleh karena itu BPRS harus sebisa mungkin mengelola SDM yang ada agar dapat efisien. Menurut Otoritas Jasa Keuangan (2017) beberapa cara yang dapat dilakukan adalah dengan mengadakan pelatihan dan pendidikan agar SDM menjadi berkualitas sehingga bisa lebih efisien dalam bekerja, mendorong program link dan match yaitu program kerjasama dengan perguruan tinggi dan industri keuangan syariah sehingga diharapkan lulusan perguruan tinggi dapat memenuhi kualifikasi kebutuhan industri perbankan syariah. Inovasi digitalisasi perbankan juga dapat mengurangi kegiatan operasional yang dilakukan secara manual sehingga dapat menekan biaya tenaga kerja. Penghematan biaya yang dikeluarkan untuk para direksi dan pengurangan pemberian tunjangan-tunjangan juga dapat dilakukan untuk menekan biaya tenaga kerja. Dari hasil olah data juga ditemukan bahwa pengelolaan asset tetap di BPRS belum optimal. Hal ini bisa mengurangi kesempatan BPRS dalam memperoleh pendapatan, dan juga kesulitan likuiditas. Oleh karena itu BPRS bisa mengurangi asset-aset tetap yang ada dengan menerapkan prinsip skala prioritas sehingga asset tetap tersebut bisa disalurkan ke asset produktif seperti memperbesar alokasi pembiayaan sehingga dapat meningkatkan keuntungan BPRS dengan memperlancar proses intermediasi, hal ini juga sekaligus bisa menambah pendapatan operasional. Selain yang telah diuraikan sebelumnya, menurut Otoritas Jasa Keuangan (2017) cara lain untuk menambah pembiayaan adalah dengan melakukan pemasaran yang menarik dengan cara yang mudah dipahami oleh masyarakat, serta menambah variasi produk-produk pembiayaan. Hal ini tentunya perlu diiringi dengan pemantauan terhadap kualitas pembiayaan serta pemantauan dan penyelesaian terhadap debitur bermasalah. Dengan meningkatnya jumlah pembiayaan maka pendapatan operasional juga akan bertambah. Cara lain untuk menambah pendapatan operasional adalah dengan memperbesar porsi jumlah aset produktif dari total aset yang dimiliki, optimalisasi peran pembiayaan dengan mengurangi Non Performing Financing (NPF) dan aktiva tetap, perbaikan kuantitas dan kualitas pelayanan jasa, dan perbaikan kualitas SDM juga dapat meningkatkan pendapatan operasional.

\section{Penutup}

\section{Kesimpulan}

Berdasarkan hasil analisis dan pembahasan yang telah diuraikan maka dapat ditarik kesimpulan sebagai berikut:

1. Bank Pembiayaan Rakyat Syariah (BPRS) di Jawa Barat selama periode 2014-2018 masih mengalami trend efisiensi yang fluktuatif dan memiliki rata-rata efisiensi sebesar 94,52\%. Hal ini menunjukan bahwa BPRS di Jawa Barat belum efisien, meskipun secara rata-rata belum efisien namun BPRS di Jawa Barat sudah mendekati titik efisien dan sudah cukup baik dalam menjalankan perannya sebagai lembaga intermediasi. Rata-rata nilai efisiensi tertinggi terjadi pada tahun 2014 sebesar 97\%. Rata-rata nilai efisiensi terendah terjadi pada tahun 2015 sebesar 91,70\%. BPRS yang selalu mencapai nilai efisiensi optimum secara konsisten selama periode penelitian adalah BPRS Harta Insan Karimah Parahyangan, BPRS Harta Insan Karimah Cibitung, dan BPRS Darut Tauhid. Sedangkan BPRS yang tidak pernah mencapai nilai efisiensi optimum salama periode penelitian adalah BPRS Al Salaam Amal Salman.

2. BPRS yang belum mencapai tingkat efisiensi optimum disebabkan karena adanya variabel input atau output yang belum berkontribusi secara masksimal dalam mencapai nilai optimumnya. Cara meningkatkan kinerja efisiensi Bank Pembiayaan Rakyat Syariah (BPRS) adalah dengan memaksimalkan input (total simpanan, biaya tenaga kerja, total asset, dan modal) dan output 
(total pembiayaan dan pendapatan operasional lainnya) yang ada sesuai dengan rekomendasi dari hasil olah data Data Envelopment Analysis (DEA). Variabel yang menjadi penyebab inefisiensi adalah variabel total pembiayaan dan pendapatan operasional lainnya pada output. Namun, secara rata-rata inefisiensi yang terjadi lebih besar disebabkan oleh total pembiayaan, artinya dana yang disalurkan untuk pembiayaan pada BPRS belum optimal.

\section{Keterbatasan Penelitian}

Dalam penyusunan Tugas Akhir ini memiliki beberapa keterbatasan antara lain:

1. Jumlah sampel yang digunakan masih sedikit dan periode penelitian yang terbatas dikarenakan ketersediaan data yang tidak lengkap.

2. Penelitian ini belum dapat menjelaskan faktor-faktor yang mempengaruhi efisiensi.

\section{Saran}

Berdasarkan hasil penelitian ini, beberapa hal yang dapat penulis sarankan antara lain:

1. Untuk penelitian selanjutnya disarankan untuk melakukan pengamatan berkelanjutan tentang efisiensi Bank Pembiayaan Rakyat Syariah (BPRS) di Jawa Barat menggunakan metode Data Envelopment Analysis (DEA) pada periode yang lebih luas, dengan sampel yang lebih besar, dan menambah variabel lainnya yang dapat mempengaruhi efisiensi, sehingga dapat menghasilkan penelitian yang lebih baik.

2. Peneliti selanjutnya juga bisa meneliti faktor-faktor apa saja yang mempengaruhi efisiensi Bank Pembiayaan Rakyat Syariah (BPRS) di Jawa Barat, sehingga dapat memperluas pembahasan bagaimana meningkatkan efisiensi BPRS di Jawa Barat untuk selanjutnya bisa bermanfaat bagi pihak-pihak yang berkepentingan.

3. Untuk BPRS yang sudah efisien diharapkan bisa mempertahankan nilai efisiensi yang sudah baik dan untuk BPRS yang belum efisiensi harus meningkatkan nilai efisiensi dengan mengoptimalkan input dan output yang dan menjalankan implikasi manajerial pada penelitian. Dilihat dari rata-rata penyebab inefisiensi, total pembiayaan adalah variabel yang menjadi sumber terbesar inefisiensi sehingga BPRS bisa melakukan berbagai upaya untuk meningkatkan penyaluran dana pembiayaan kepada nasabah seperti melakukan pemasaran yang menarik dengan cara yang mudah dipahami oleh masyarakat, menambah variasi produk-produk pembiayaan serta upaya lainnya.

\section{Daftar Pustaka}

Ascarya. (2017). Comparing the Technical Efficiency of Leading Baitul Maal wat Tamwil and Conventional Cooperatives in Indonesia. Islamic Economic and Finance Department, Bank Indonesia, March, 1-13.

Basse, I. P., \& Mulazid, A. S. (2017). Analisa Pengaruh Kualitas Aset, Likuiditas, Efensiensi Usaha Dan Profitabilitas Terhadap Rasio Kecukupan Modal Pada Umum Syariah Periode 20122015. Al-Tijary Jurnal Ekonomi Dan Bisnis Islam, 2(2), 109. https://doi.org/10.21093/at.v2i2.677

Berger, A. N., \& Humphrey, D. B. (1997). Efficiency of financial institutions: international survey and directions for future research. European Journal on Operatinoal Research, 98(2), 175-212.

Hadad et al. (2003). Analisis Efisiensi Industri Perbankan Indonesia: Penggunaan Metode Nonparametrik Data Envelopment Analysis (Dea). Bank Indonesia Research Paper.

Hamara, E. (2017). Analisis Efisiensi BPR dan BPRS di Kabupaten Bogor. Institut Pertanian Bogor Bogor.

Hardianto, D. S., \& Wulandari, P. (2016). Islamic Bank vs Conventional Bank: Intermediation, Fee 
Based Service Activity and Efficiency. International Journal of Islamic and Middle Eastern Finance and Management Emerald, 9(2), 296-311. https://doi.org/10.1108/IMEFM-01-2015-0003

Hidayah, N. (2014). Studi Komparatif Tingkat Efisiensi Perbankan Konvensional dan Perbankan Syariah di Indonesia. Jurnal Ekonomi \& Kenangan Islam Seminar Nasional Da Call for Paper (Sancall 2014), 2(2), 28-37. https://doi.org/10.20885/jeki.vol2.iss2.art4

Hidayat, H. R. (2011). Kajian Efisiensi Perbankan Syariah di Indonesia (Pendekatan Data Envelopment Analysis). Media Riset Bisnis Dan Manajemen Univerisiti Kebangsaan Malaysia, 11 No. 1,1-19.

Hidayat, H. R. (2014). Efisiensi Perbankan Syariab: Teori dan Praktek. Gramata Publishing.

Hijriyani, N. Z., \& Setiawan. (2017). Analisis Profitabilitas Perbankan Syariah di Indonesia sebagai Dampak Dari Efisiensi Operasional. Jurnal Kajian Akuntansi, 1(2), 194-209. https://doi.org/10.33603/jka.v1i2.823

IFDI. (2019). Islamic Finance Development Report 2019 Shifting Dynamics.

IFSB. (2019). Islamic Financial Services Industry Stability Report 2019.

Mahinda et al. (2015). Efficiency of micro finance institutions in Sri Lanka : a two-stage double bootstrap DEA approach. 47, 74-83. https://doi.org/10.1016/j.econmod.2015.02.016

Mokhtar, H. S. A. et al. (2006). Efficiency of Islamic Banking in Malaysia: a Stochastic Frontier Approach. Journal of Economic Cooperation, 27(2), 37-70.

Muharam, H., \& Pusvitasari, R. (2007). Analisis Perbandingan Efisiensi Bank Syariah di Indonesia Dengan Metode Data Envelopment Analysis (periode Tahun 2005). Jumal Ekonomi Dan Bisnis Islam, II(3), 80-166.

OJK. (2017). Roadmap Pengembangan Keuangan Syariah 2017-2019.

Otoritas Jasa Keuangan. (2018). Statistik Perbanakan Syariah.

Otoritas Jasa Keuangan. (2019). Statistik Perbankan Syariah.

Reuters, T., \& Standard, D. (2018). State of the Global Islamic Economy Report 2018. In Dubai International Financial Centre. https:// haladinar.io/hdn/doc/report2018.pdf

Setiawan, \& dkk. (2020). Pengukuran Tingkat Kinerja Keuangan dan Kinerja Non Keuangan Pada Bank Syariah di Lima Negara Asia (Studi Kasus pada Bank Syariah dengan Aset Tertinggi). Dinamika Akuntansi, Kenangan Dan Perbankan, 9. https://doi.org/10.1017/CBO9781107415324.004

Setyowati, D. H. (2018). Analisis Kinerja Keuangan Bank Umum Syariah Sebagai Dampak Inefisiensi Operasional. Jurnal Maps (Manajemen Perbankan Syariah), 1-14. https://doi.org/https://doi.org/10.32483/maps.v3i1.31

Sufian, F., \& Kamarudin, F. (2015). Determinants of revenue efficiency of Islamic banks: Empirical evidence from the Southeast Asian countries. International Journal of Islamic and Middle Eastern Finance and Management, 8(1), 36-63. https://doi.org/10.1108/IMEFM-12-2012-0114

Sugiono. (2016). Metode Penelitian Pendidikan Pendekatan Kuantitatif, kualitatif,dan R\&D. Alfabeta.

Zarrouk et al. (2017). Financial development, Islamic finance and economic growth: evidence of the UAE. Journal of Islamic Accounting and Business Research, Vol. 8 No.(Unit 07), 1-23. https://doi.org/10.1108/JIABR-05-2015-0020 